Uniwersytet im. Adama Mickiewicza w Poznaniu

\title{
Polityczne public relations podczas kampanii wyborczych $w$ III RP
}

$\mathrm{D}$ OŚWIAdCZENIA POLSKIEgo POLITYCZNEgo PR TO ZALEDWIE 25 LAT. Nie sposób tego przyrównywać do doświadczeń państw zachodnich, szczególnie Stanów Zjednoczonych, gdzie tak naprawdę z zagadnieniem tym, mamy do czynienia od ponad pół wieku. Porównanie do Stanów Zjednoczonych, czy też do innych krajów zachodniego kręgu kulturowego, może nam jednak dać odpowiedź na pytanie, czy w Polsce poziom profesjonalizacji komunikowania politycznego w okresie poprzedzającym wybory jest wysoki. Decydować o tym będzie oczywiście przyswojenie (i co ważne zastosowanie w działaniu) przez podmioty rywalizacji wyborczej nowych i skutecznych metod przekonania wyborców, opracowanych przez specjalistów z pogranicza świata nauki i praktyki politycznej (Mazur, 2010, s. 26). W Polsce już w latach 90-tych XX w. starano się korzystać z ekspertów z zakresu komunikowania, jednak nie zawsze przekładało się to na sukcesy wyborcze poszczególnych kandydatów i partii. Czy zatem analizując poszczególne kampanie wyborcze w Polsce od początku lat 90-tych XX w. możemy stwierdzić, że znaczenie profesjonalizmu komunikacji politycznejwzrosło dopierowmomenciezałamaniasięrywalizacjiobozu postkomunistycznegozpostsolidarnościowym? Rozwójprofesjonalizacji jest elementem szerszego zjawiska, a mianowicie tzw. amerykanizacji kampanii wyborczych. Amerykanizacji, na którą oprócz wspomnianej wyżej profesjonalizacji składa się także personalizacja samych wyborów, wykorzystywanie na szeroką skalę przekazów negatywnych wobec oponentów oraz zarządzanie wydarzeniami i tematami (które są narzucane przez poszczególne sztaby mediom) (Shultz, 2006, S. $141-146)$.

\section{CZYM JEST POLITYCZNY PR?}

ABY ZDEFINIOWAĆ POLITYCZNE PUBLIC RELATIONS, NALEŻY NAJPIERW ZASTANOWIĆ się czym jest sam PR. Odwołując się do znaczenia leksykalnego należy stwierdzić, że są to wszelkiego rodzaju stosunki publiczne. Nie 
mają one jednak charakteru materialnego, bowiem odnoszą się sfery psychologicznej. Pojęcie to narodziło się w Stanach Zjednoczonych już w XVIII w., kiedy to po raz pierwszy użył go prezydent Thomas Jefferson. Na przełomie XIX i XX w. PR zaczął być utożsamiany z opiniami o towarach lub usługach oferowanych przez prywatne firmy. Klasycznym tego przykładem w tamtym okresie były działania podejmowane przez przedsiębiorstwa kolejowe w Stanach Zjednoczonych. Firmy odpowiedziały w ten sposób na publiczna krytykę dotyczącą ich usług, która bezpośrednio odbijała się na wynikach finansowych (Święćkowska, 2008, s. 17). Takie działania były definiowane jako tzw. public direction. $Z$ biegiem lat pojęcie PR weszło na dobre do codziennego życia, a także stało się odrębną dziedziną badań. W dzisiejszej literaturze PR najczęściej definiuje się jako zarządzanie komunikowaniem danego podmiotu (organizacji, instytucji) z otoczeniem.

Bez pozytywnego wizerunku nie ma poparcia, a bez poparcia nie ma życia na scenie politycznej. Istotą politycznego PR jest kształtowanie dobrego image'u ugrupowania bądź polityka. Przekładając to na czysto praktyczną sferę, są to wszystkie zabiegi, które mają wzmocnić pozycję danej partii (Podobas, 2012, s. 172). Dotyczy to oczywiście zwiększenia jej reprezentacji w parlamencie, czy też wybrania jej kandydata (tak jak to się dzieje w przypadku wyborów prezydenckich). Pośrednio może to dotyczyć przekonania do ideologii lub programu (Wójcik, 2009, s. 811). Jednak nie tylko partie muszą dbać o pozytywny PR. Podmiotami politycznego public relations mogą być także instytucje władzy państwowej lub organy samorządu terytorialnego. Warto zwrócić uwagę, że budowanie korzystnego wizerunku jest procesem ciągłym. Lojalność (zwłaszcza wyborców) nie jest czymś, co nie ulega zmianie. To, że ludzie raz zaufali danej partii, czy kandydatowi nie oznacza, że zawsze będą tak robić. W literaturze i metodach sondażowych określa się to mianem przepływu elektoratu. Ów przepływ szczególnie w polskich warunkach jest czymś zupełnie normalnym. Dochodzić może nawet do przypadków popierania raz ugrupowania prawicowego, a innym razem lewicowego, co z punktu widzenia analizy politologicznej wydaje się być czymś zupełnie absurdalnym i niewytłumaczalnym. Jednak to tylko pokazuje jak duże znaczenie we współczesnej polityce ma sam wizerunek, a nie wartości czy program, które stoją za partią.

Charakteryzując polityczny PR warto także zaznaczyć, że jest on obok reklamy narzędziem komunikacji marketingowej. Bardzo często mylnie polityczne public relations utożsamia się z propagandą. 
Pomimo, że mają bardzo podobne cele (wpływają na opinie, postawy i zachowania ludzi) to jednak różni je sama koncepcja działań. Propaganda jest bowiem jednokierunkowym oddziaływaniem, którego „celem jest wywieranie wpływu na kształtowanie myśli, postaw, przekonań i zachowań zbiorowości ludzi w stosunku do spraw publicznych lub określonych wartości politycznych, religijnych, moralnych zgodnie z życzeniem tego, kto właśnie tym sposobem posługuje się lub go afirmuje" (Sztumski, 1990, s. 30). Propaganda zawsze ma przynosić korzyści nadawcy, niekonieczne jednak odbiorcy. Tymczasem PR ma tworzyć pozytywne relacje między nadawcą a odbiorcą, bazując na wzajemnym zaufaniu (Mazur, 2002, s. 44-46).

Kto jest adresatem politycznego PR? Najczęściej są to dwie grupy. Może być on skierowany albo do członków danej partii politycznej (tzw. wewnętrzny PR) albo do szeroko rozumianej publiczności (tzw. zewnętrzny PR). Narzędziami wewnętrznego PR mogą być np. poczta, spotkania, zjazdy, biuletyny informacyjne, czyli wszystko to, co rozprzestrzenia się za pomocą wewnątrzpartyjnych kanałów komunikowania. Zewnętrzny PR ma na celu z kolei dotarcie i przekonanie jak największej grupy odbiorców. W tym celu wykorzystuje się wszelkie środki masowego przekazu, choć nie tylko. To także bezpośrednie spotkania z ludźmi, którzy są dla partii potencjalnymi wyborcami.

Polityczny PR oczywiście nie odnosi się tylko do okresu kampanii wyborczej. Politycy, którzy dostali mandat społeczny do pełnienia pewnych funkcji, dalej muszą dbać o swój dobry wizerunek. Można jednak stwierdzić, że w trakcie kampanii podmioty polityczne dążą do uzyskania poparcia tzw. miękkiego elektoratu (czyli wyborców niezdecydowanych lub popierających ugrupowania konkurencyjne). Natomiast w okresie kiedy nie ma wyborów swój przekaz kierują raczej do swoich zwolenników (Wójcik, 2009, s. 812).

Polityczny PR jest zawsze działaniem zamierzonym. Ma być wiarygodnym źródłem informacji o danym podmiocie politycznym. Rzetelność, prawdziwość i aktualność to cechy informacji, które są jego istotą. Rozwój techniki spowodował, że żyjemy obecnie w świece zdominowanym przez środki masowego przekazu. Prasa, radio, telewizja oraz Internet, każdego dnia zasypują nas garściami informacji z różnych dziedzin życia, w tym także z polityki (Mazur, 2002, s. 24). Bardzo często obraz partii politycznej, czy polityka budujemy wyłącznie na podstawie przekazów medialnych. Wydaje się, że sukces łączy się nieodzownie z dobrą prezentacją w środkach masowego przekazu. Aby go osiągnąć, partie polityczne coraz częściej sięgają po specjalistów 
z tej dziedziny, czyli tzw. spin doktorów. Sama nazwa wywodzi się od ludzi ze sztabów wyborczych Ronalda Regana i Waltera Mondale, którzy w 1984 r. w trakcie kampanii wyborczej próbując ukryć wszelkie wady, skupiali się na prezentowaniu silnych stron swoich kandydatów (Błaszczak, 2008). Współcześnie to właśnie spin doktorzy decydują jakich środków i technik użyć, aby przekuło się to na sukces wyborczy. Jednak wiele osób ma krytyczne zdanie o ich pracy. Wśród zarzutów najczęściej podnosi się ten, że poprzez działania wizerunkowe obniża się poziom debaty publicznej. Skupianie się na dobrym opakowaniu powoduje, że argumenty polityczne są trywializowane, a programy zastępowane są przez cechy osobowościowe polityków (Street, 2006, s. 159).

\section{LATA 9O-TE - CZYLI WALKA OBOZU POSTSOLIDARNOŚCIOWEGO Z POSTKOMUNI- STYCZNYM ZE WZORCAMI ZACHODNIMI W TLE}

NA KOMUNIKOWANIE POLITYCZNE POSZCZEGÓLNYCH PARTII I KANDYDATÓW w latach 90-tych XX w. ogromny wpływ miały wzorce amerykańskie. Bardzo często były one przeszczepiane z rynku amerykańskiego na polski, bez uwzględnienia tutejszych czynników kulturowych oraz instytucjonalnych. Przenikały one do Polski poprzez różne instytucje takie jak np. International Republican Institute czy National Democratic Institute (wspierały one kampanie komitetów obywatelskich w pierwszej elekcji parlamentarnej). Warto także zauważyć, że charakterystyczną cechą wyborów w Polsce w latach 90-tych XX w. była rywalizacja pomiędzy partiami (czy kandydatami w wyborach prezydenckich) pochodzącymi z dwóch różnych obozów - postsolidarnościowego oraz postkomunistycznego. Ciekawym przedmiotem analizy jest pewnością prezydencka kampania z 1990 r. Wtedy to o urząd Prezydenta RP ubiegało się 6-ciu kandydatów. Tamtejsze wybory pokazały, że w państwie, które zmaga się z problemami gospodarczymi (wynikającymi z przejścia z gospodarki centralnie planowanej na wolnorynkową) sprawnie poprowadzona kampania, może przynieść ogromny sukces populistycznym silom politycznym. Człowiek znikąd, za jakiego w tamtym czasie uchodził Stanisław Tymiński, pokonał w pierwszej turze takich kandydatów jak Włodzimierz Cimoszewicz, czy Tadeusz Mazowiecki i dostał się do decydującej batalii razem z Lechem Wałęsą. W kampanii wyborczej karierę zrobiła szczególnie „czarna teczka” S. Tymińskiego, w której to miały się znajdować skuteczne plany ratowania polskiej gospodarki, oraz dokumenty kompromitujące lidera „Solidarności” (Pająk, Patkowski, 2007, s. 139). Człowiekowi, 
który nawet nie mieszkał na stałe w Polsce, zaufało w wyborach prawie 4 miliony osób. Wynik pierwszej tury był porażką ówczesnego premiera - T. Mazowieckiego (Alberski, 2002, s. 104). Sondaże, które jeszcze przed wyborami dawały mu ponad $20 \%$ poparcia, zupełnie nie znalazły odzwierciedlenia podczas głosowania. Niewątpliwie do tak słabego wyniku T. Mazowieckiego przyczyniła się mało dynamiczna kampania prowadzona przez jego sztab. Premier w telewizji mówił wolno, a jego spoty wyborcze przedstawiały go bardziej jako zmęczonego urzędnika niż prężnego lidera. O sile mediów (a zwłaszcza telewizji) wiedział za to S. Tymiński, który w Peru posiadał własną telewizję kablową. W jego spotach i reklamówkach kładziono nacisk na sam obraz, a nie prezentację programu wyborczego. Ujęcia z dużych wieców, gdzie zgromadzona publiczność skandowała jego nazwisko bardziej oddziaływały na wyborców (Morozowski, 2007). Większość kandydatów niestety nie zdawała sobie wówczas sprawy, że bardziej od tego co się mówi ważniejsze jest to, w jaki sposób się to robi i jak się to zaprezentuje. W podobnym charakterze przebiegała kampania wyborcza do parlamentu w 1991 r. Wtedy to, tak samo jak w 1990 r., główną rolę odgrywały telewizyjne reklamówki wyborcze. Za ich treść odpowiadały sztaby wyborcze poszczególnych partii. W telewizyjnych reklamówkach kandydaci z zza biurka studia telewizyjnego wygłaszali podobnie brzmiące hasła i slogany, które trafiały głównie do ich elektoratów. Co ważne, w kampanii tej dominowały głównie przekazy negatywne. Wiele ugrupowań koncentrowało się na atakowaniu konkurencji, a nie przedstawianiu własnych programów. Wiązało się to też z tym, że wówczas na polskiej scenie politycznej mieliśmy do czynienia z dużym rozbiciem partyjnym (Ratajczak, 2009).

W kolejnych latach poszczególne partie czy kandydaci, starali się prowadzić kampanie wyborcze przy pomocy konsultantów z Europy Zachodniej. Po raz kolejny wtedy wiele sztabów przekonało się, że przenoszenie bezpośrednich wzorców z krajów zachodnich nie gwarantuje sukcesu wyborczego. $\mathrm{Z}$ takiego założenia nie wyszły osoby odpowiedzialne za kampanie Kongresu Liberalno-Demokratycznego. Firma Saatchi \& Saatchi, która została wówczas wynajęta przez KLD, odwołując się do wzorców amerykańskich, postawiła w kampanii nacisk na kwestie związane z gospodarką. Hasłem Kongresu LiberalnoDemokratycznego było „Milion nowych miejsc pracy”, które w sytuacji bezrobocia (o spowodowanie którego, byli oskarżani liberałowie), wielu wyborców potraktowało jako przekaz ironiczny. Efektem tej błędnej strategii, był słaby wynik KLD w samych wyborach, bowiem 
liberałowie uzyskując niecałe $4 \%$ poparcia, nie weszli nawet do Sejmu. W 1995 r. (w kampanii prezydenckiej) kandydatom prawicowym (Hannie Gronkiewicz-Waltz, L. Wałęsie) doradzali ludzie odpowiedzialni za kampanie konserwatystów w Wielkiej Brytanii (w 1992 r.). Jacek Kuroń współpracował z kolei z dyrektorem Instytutu Filozofii i Socjologii PAN Andrzejem Rychardem. W kampanii tej po raz pierwszy pojawiły się także płatne reklamy wyborcze. Sztaby komitetów Jana Olszewskiego, Waldemara Pawlaka, oraz H. Gronkiewicz-Waltz zdecydowały się na taki właśnie sposób komunikowania z ludźmi (Wiszniowski, 2000, s. 165 - 167). Wybory wygrał popierany przez SLD Aleksander Kwaśniewski (Wróblewski, 2007, s 473). O jego końcowym sukcesie przesądziły dwie wygrane debaty telewizyjne. A. Kwaśniewski na tle L. Wałęsy jawił się jako polityk odpowiedzialny i prawdziwy mąż stanu (Alberski, 2002, s. 108). Za zwycięstwem kandydata SLD stał cały sztab specjalistów, z Jacques Seguelem na czele. A. Kwaśniewski wg koncepcji J. Seguela miał być prezydentem wszystkich Polaków. Hasło wyborcze „Wybierzmy przyszłość” pokazywało kandydata SLD jako ucieleśnienie nowoczesności i postępu. Zupełnie inaczej na jego tle wypadał L. Wałęsa. Ówczesny Prezydent zwracał się w swojej kampanii głównie do elektoratu antykomunistycznego (Mazur, 2007, s. 214). Byłemu przewodniczącemu „Solidarności” popularności nie przysparzały także gafy, które popełniał w trakcie jej trwania. Do historii przeszły już jego zdania wypowiedziane po debacie telewizyjnej skierowane do A. Kwaśniewskiego: „To Pan rozpoczął niekulturalnie. Dobrze, że się pan zreflektował, przecież Pan wszedł tak, jak do obory, ani be, ani me, ani kukuryku" (Ratajczak, 2009).

W 1997 r. pod raz pierwszy w historii Polski w kampanii wyborczej wykorzystano Internet, który posłużył jako dodatkowa forma kontaktu z wyborcami. Sztaby dwóch największych formacji (czyli SLD oraz AWS-u) starały się głównie promować swoich liderów. Partie w tej kampanii chciały trafić do różnych elektoratów. AWS - do całego obozu postsolidarnościowego, Unia Wolności do byłych wyborców KLD, a SLD do wyborców lewicowych, oraz tęskniących za czasami PRL-u (Wiszniowski, 2000, s. 170 - 171). Debata polityczna oscylowała wokół rozliczenia rządów SLD - PSL, a także wokół lustracji i reprywatyzacji. Wybory te ostatecznie zakończyły się porażką lewicy. Niewątpliwie przyczynił się do tego premier W. Cimoszewicz, który w czasie tzw. „powodzi tysiąclecia” w lipcu 1997 r. stwierdzil, że mieszkańcy podtopionych terenów powinni byli się ubezpieczyć, a nie liczyć na pomoc państwa. Przypadek ten pokazuje, jak jedna niefortunna wypowiedź 
(zarejestrowana przez media) może zdyskredytować polityka i mieć później wpływ na wynik wyborczy (Jednaka, 2002, s. 91).

Kolejne dwie kampanie nie przyniosły istotnych zmian w formule ich prowadzenia. Były może o tyle wyjątkowe, że zarówno w 2000 jak i w $2001 \mathrm{r}$. mieliśmy od początku do końca jednego faworyta. W wyborach prezydenckich był nim A. Kwaśniewski, a w wyborach parlamentarnych 2001 r. Sojusz Lewicy Demokratycznej. W 2000 . A. Kwaśniewski, we wszystkich sondażach wyprzedzał swoich konkurentów. Sztab prezydenta koncentrował się nad tym, aby już w pierwszej turze zdobyć bezwzględność większość głosów. Głównymi jego rywalami w walce o reelekcje byli Marian Krzaklewski (kandydat popierany przez AWS i NSZZ „Solidarność”) oraz Andrzej Olechowski (popierany przez środowiska liberalne). Wynik głosowania, nie pozostawiał złudzeń kto cieszył się wówczas największym poparciem wśród wyborców. A. Kwaśniewski uzyskał 53,9 \% wszystkich głosów i zwyciężył już w pierwszej turze wyborów (Raciborski, 2003, s. 224). Słaby wynik M. Krzaklewskiego był efektem rozczarowania społeczeństwa 3-letnim okresem rządów AWS-u. Wydaje się, że A. Kwaśniewskiemu nie zaszkodziła nawet reklama negatywna, za którą stał sztab ówczesnego lidera prawicy. W jednym z przedwyborczych spotów przedstawiono materiał z wizyty prezydenta w Kaliszu, na którym Marek Siwiec (minister w kancelarii A. Kwaśniewskiego) wykonywał charakterystyczny znak krzyża i całował po wyjściu z helikoptera ziemię. Gest ten miał jednoznacznie kojarzyć się wszystkim z pielgrzymkami Jana Pawła II i błogosławieństwem, które zawsze po opuszczeniu pokładu samolotu wykonywał Ojciec Święty. W spocie słyszymy słowa, że: „Za chwilę zobaczymy zachowanie A. Kwaśniewskiego, które dyskwalifikuje go jako kandydata do zaszczytnej funkcji Prezydenta Rzeczypospolitej (...) Teraz rozbawiony Kwaśniewski będzie zachęcał swojego ministra do dalszych szyderstw z Ojca Świętego”. Jest jeden z klasycznych przykładów na to, że nie zawsze reklama negatywna uderza w bezpośredniego adresata. Bardzo często (tak jak w tym przypadku) odbija się również negatywnie na wyniku kandydata promującego taki spot (Daniel, 2011). Warto także wspomnieć, że 18 \% poparcie, uzyskane przez A. Olechowskiego zapoczątkowało nowy projekt polityczny. To właśnie dobry wynik wyborczy skłonił byłego Ministra Spraw Zagranicznych do założenia (wspólnie z Donaldem Tuskiem i Maciejem Płażyńskim) Platformy Obywatelskiej .

Podobny charakter miała parlamentarna kampania wyborcza w 2001 r. Tutaj też od samego początku faworyt do zwycięstwa był 
tylko jeden. SLD, które w kampanii skupiało się wyłącznie na kontestowaniu rządów prawicy, uzyskało 41 \% głosów. Rządząca AWS nie przekroczyła nawet progu wyborczego (Wiatr, 2003, s. 117). Trzeba jednak zauważyć, że nawet tak wysoka wygrana nie zadowoliła w pełni ówczesnego lidera SLD Leszka Milera. Jemu oraz innym kluczowym politykom tej partii zależało bowiem na zwycięstwie, które pozwoliłby na samodzielne rządy, bez konieczności wchodzenia w koalicję z innym ugrupowaniem. Była to stosunkowo realna perspektywa, bowiem niektóre sondaże przeprowadzane w kampanii wyborczej przewidywały taki właśnie scenariusz. Tym co mogło przeszkodzić w zdobyciu większości bezwzględnej, były wypowiedzi Marka Belki w ostatnim tygodniu przed wyborami. Swoimi poglądami na temat programu radykalnych oszczędności (które musiały zostać wprowadzone ze względu na tzw. „dziurę budżetową Bauca”) odebrał lewicowej koalicji część głosów.

KAMPANIE POD ZNAKIEM „ŻELAZNEGO UŚCISKU” KaCZYŃSKIEGO I TUSKA

W OSTATNICH LATACH POSZCZEGÓLNE PARTIE PRZYKŁADAJĄ OGROMNĄ WAGE do jakości komunikowania politycznego podczas kampanii wyborczych. Dzisiaj sztaby dalej starają się nadążać za najnowszymi trendami (wyznaczonymi najczęściej przez kampanie amerykańskie), ale uwzględniają lokalne uwarunkowania instytucjonalne i kulturowe. Biorąc pod uwagę niezwykłą chwiejność elektoratu, strategie poszczególnych sztabów skupiają się na skutecznych działaniach głównie w okresie samej kampanii. Pewną cezurą wyznaczającą nowy etap w rywalizacji wyborczej w Polsce były podwójne wybory przeprowadzone w 2005 r. Wtedy to, po raz pierwszy w historii III RP, o zwycięstwo parlamentarne walczyły dwa ugrupowania o rodowodzie postsolidarnościowym, czyli PiS oraz PO. Załamanie się podziału na obóz postsolidarnościowy i postkomunistyczny zwiększyło nieprzewidywalność wyników poszczególnych wyborów (Mazur, 2010, s. 28 - 29). Kampanie parlamentarne z 2005, 2007 i 2011 r. potwierdzają tę tezę, ponieważ trudno było wskazać wyraźnego faworyta do końcowego triumfu. Zwycięstwo Prawa i Sprawiedliwości w 2005r. to zasługa bardzo dobrze poprowadzonej na finiszu kampanii. Adam Bielan i Michał Kamiński (czyli główni spin doktorzy PiS-u) wymyślając pomysł z podziałem Polski na „solidarną” i „liberalną”, skutecznie odwiedli część społeczeństwa od zagłosowania na PO (Pająk, Patkowski, 2007, s. 142). Spot wyborczy z pustą lodówką przeszedł już do historii polskiej reklamy politycznej. A. Bielan i M. Kamiński odnieśli 
podwójny sukces bowiem oprócz zwycięstwa PiS-u w wyborach parlamentarnych, udało im się doprowadzić do triumfu Lecha Kaczyńskiego w wyborach prezydenckich (Markowski, 2007, s. 162 - 163). Dużą rolę odegrała także debata w TVP 1 przed drugą turą wyborów, w której to ówczesny Prezydent Warszawy wypadł lepiej niż D. Tusk.

Dwa lata rządów PiS-u dostarczyły nie lada emocji wyborcom. Brak porozumienia z PO, zawiązanie tzw. paktu stabilizacyjnego, a następnie koalicji z Samoobroną i LPR-em oraz późniejsze jej zerwanie spowodowały, że w 2007 r. doszło do skrócenia kadencji Sejmu (Węgorzecki, 2008, s. 16). Wybory (podobnie jak te z 2005 r.) stały pod znakiem rywalizacji PiS-u i Platformy. W tej kampanii skuteczniejsi okazali się sztabowcy PO. Za sukcesem partii D. Tuska stał szef agencji Alert Media Communications Adam Łaszyn. To on doradzał liderowi Platformy, jak ma się zachowywać w dwóch głównych debatach kampanii (Dziedzic, Miziołek, Wojciechowska, 2013). To one w znacznym stopniu przyczyniły się do zwycięstwa Platformy, ponieważ D. Tusk zarówno w rozmowie z Jarosławem Kaczyńskim jak i z A. Kwaśniewskim wypadł lepiej niż jego oponenci. Podczas dyskusji z liderem PiS-u D. Tusk wykazał się znajomością cen chleba, czy ziemniaków, co mogło wytworzyć u wyborców przekonanie, że nie są mu obce problemy, z którymi na co dzień zmagają się Polacy. To A. Łaszyn doradził także liderowi PO, żeby ten namawiał wyborców lewicy do zagłosowania na Platformę w tych wyborach. Partia braci Kaczyńskich swój sukces chciała z kolei, po raz kolejny, oprzeć na dychotomicznym podziale na Polskę „solidarną” oraz „liberalną”. W spotach pokazywała się wyborcom jako ugrupowanie, które jako jedyne umie skutecznie walczyć z korupcją. W reklamówkach telewizyjnych przedstawiano PO oraz SLD jako partie, które będąc częścią tzw. „układu” tworzą nieformalne powiązania świata polityki i biznesu. Do historii polskiej reklamy politycznej przeszły z pewnością spoty takie jak: „Mordo Ty moja (salon)”, czy „Niedawno temu w Polsce ...”. Warto także wspomnieć, że A. Łaszyn doradzał PO interpretowanie przekazu PiS, jako swoistego zagrożenia dla stabilności naszego państwa. W tych wyborach słaby wynik osiągnęła również lewica, która szła pod szyldem LiD-u (czyli „Lewica i Demokraci”). LiD łącznie uzyskał niespełna 14 \% poparcia, co przełożyło się na tylko 53 mandaty w Sejmie. Wynik ten to w dużej mierze wypadkowa błędów popełnionych w kampanii przez A. Kwaśniewskiego, który jeszcze przed wyborami został wytypowany na kandydata tego ugrupowania na premiera. Były prezydent miał spełniać funkcję tzw. lokomotywy wyborczej i być 
twarzą doraźnie powstałej koalicji. Jednak A. Kwaśniewski pomimo, iż w debatach przedwyborczych z J. Kaczyńskim i D. Tuskiem wypadał nieźle, to jednak podczas kampanii zdarzały mu się wpadki. Dotyczy to głównie publicznych wystąpień byłego prezydenta w Szczecinie i w Kijowie, podczas których wyraźnie był pod wpływem alkoholu (Peszyński, 2008, s. 87). Szczególnie zdania wypowiedziane na Pomorzu, odnoszące się do Ludwika Dorna i jego psa Saby, zostały mocno zapamiętane przez wyborców.

Zupełnie odmienna od poprzednich, była kampania prezydencka w 2010 r. Oczywiście miała na to wpływ ogromna tragedia narodowa, jaką była katastrofa smoleńska. Śmierć prezydenta L. Kaczyńskiego oraz innych przedstawicieli polskiej klasy politycznej wstrząsnęła całym krajem. Wydarzenie to wpłynęło na samą kampanię, która miała o wiele spokojniejszy charakter. Unikano bezpośrednich ataków na konkurentów i starano się prezentować bardziej pozytywny program. Strategię taką obrały sztaby dwóch najpoważniejszych kandydatów na urząd Prezydenta, czyli komitety Bronisława Komorowskiego oraz J. Kaczyńskiego. Szczególnie pozytywnie oceniono kampanie lidera Prawa i Sprawiedliwości. To w jej trakcie J. Kaczyński został przedstawiony jako polityk, który chcę zakończyć „wojnę polsko - polską”, i który będzie dążył do poprawy stosunków z Rosją (słynne „Orędzie do Rosjan", wystosowane 9 maja 2010 r.) (Szacki, 2010). Za kampanie wyborczą prezesa PiS-u w tych wyborach odpowiadali w największej mierze: Jolanta Kluzik-Rostkowska, Paweł Poncyliusz, oraz Marek Migalski. To oni przekonali brata tragicznie zmarłego prezydenta do niepodejmowania $\mathrm{w}$ trakcie kampanii tematu katastrofy smoleńskiej oraz złagodzenia samej retoryki. Warto jednak wspomnieć o tym co działo się przed 10 kwietnia $2010 \mathrm{r}$. Na początku tamtego roku publicyści zastanawiali się, czy podczas głosowania dojdzie do ponownego starcia L. Kaczyńskiego z D. Tuskiem. W styczniu 2010 r. lider PO uciął jednak wszelkie spekulacje na ten temat i ogłosił, że nie będzie się ubiegał o najwyższy urząd w państwie. Swoją decyzję uzasadnił tym, iż prawdziwa władza leży w ręku premiera i że to z nią wiąże się większa odpowiedzialność za losy Polski (Paradowska, 2010). Decyzja D. Tuska miała swoje daleko idące konsekwencje. Od tej pory przeciwnicy polityczni PO nie mogli już posługiwać się argumentami, że były lider KLD dba o swój dobry PR, by tylko dotrwać do wyborów prezydenckich. Platforma musiała za to odpowiedzieć sobie na pytanie, kto będzie najlepszym jej kandydatem w nadchodzących wyborach. Zdecydowano się na wariant wewnętrznych prawyborów. Wszyscy 
członkowie Platformy mieli w tajnym głosowaniu zdecydować, który z jej polityków stanie do rywalizacji z L. Kaczyńskim. Wyłoniono dwóch kandydatów - Ministra Spraw Zagranicznych Radosława Sikorskiego oraz ówczesnego Marszałka Sejmu B. Komorowskiego. Zarządzenie prawyborów (z punktu widzenia PO) było dobrym pomysłem, bowiem rywalizacją B. Komorowskiego z R. Sikorskim żyły przez blisko dwa miesiące wszystkie media $\mathrm{w}$ Polsce, co skutecznie odwróciło uwagę od innych partii politycznych (Wybory, 2010). Ostatecznie z dużą przewagą wewnątrzpartyjne prawybory wygrał ówczesny Marszałek Sejmu. Uzyskał on niemal 69 \% poparcia wszystkich członków Platformy. W politycznych kuluarach bardzo często mówiło się, że wynik prawyborów był znany już od początku, a całe wydarzenie było tylko spektaklem medialnym.

W 2011 r. kampania wyborcza nie miała już tak łagodnego charakteru jak ta z 2010 r. Głównym konkurentem rządzącej Platformy Obywatelskiej (podobnie jak w 2005 i 2007 r.) było Prawo i Sprawiedliwość. W kampanii PiS starało się zmienić swój dotychczasowy wizerunek. Politycy tej partii podejmowali szereg działań, które miały otworzyć ją na nowy elektorat. Na konferencjach prasowych bardzo często J. Kaczyński występował w otoczeniu młodych kandydatek do Sejmu, które de facto były wyborczymi twarzami Prawa i Sprawiedliwości (Subotić, Niewińska, 2011). Innym bohaterem kampanii wykorzystanym przez partię J. Kaczyńskiego był hodowca papryki Stanisław Kowalczyk. Zasłynął on zdaniem, które wystosował do D. Tuska po przejściu huraganu w okolicach Radomia. Pytanie „Jak żyć Panie premierze?” było jednym z najczęściej wykorzystywanych przez PiS sloganów podczas tej kampanii (Grochal, 2011). Platforma bardzo często poruszała $\mathrm{z}$ kolei $\mathrm{w}$ mediach temat rozpoczętych inwestycji w naszym kraju. Hasło „Polska w budowie” było doskonałym tego odzwierciedleniem. W kampanię bardzo mocno zaangażował się sam D. Tusk. W połowie września specjalnie wynajętym autokarem (tzw. „tuskobusem”) wyruszył w Polskę, by z bliska dowiedzieć się z jakimi problemami zmagają się na co dzień Polacy. W tym czasie można było odnieść wrażenie, że to właśnie D. Tusk wziął na siebie cały ciężar kampanii wyborczej. Podczas wizyt w różnych miejscach w Polsce nie raz bowiem spotykał się z niewygodnymi pytaniami ze strony wyborców (Czupryn, 2011). Warto jednak zauważyć, że od tego czasu notowania PO zaczęły w końcu zwyżkować we wszelkich sondażach. Mimo, że podróżom tym towarzyszyły kamery i często rejestrowały wszystkie niewygodne pytania, to jednak nie zaszkodzily one wynikowi Platfor- 
my. Można powiedzieć, że poprzez odważne rozmawianie z wyborcami D. Tusk przysporzył swojemu ugrupowaniu kilka niezwykle cennych punktów procentowych.

Kampania prezydencka w 2015 r. ukazała z kolei potęgę innego medium, a mianowicie Internetu. Sztab B. Komorowskiego zupełnie zlekceważył ten sposób komunikacji z wyborcami, co spowodowało, że wielu młodych ludzi (którzy najczęściej są użytkownikami tzw. sieci) nie zagłosowało na urzędującego prezydenta, a poparło w pierwszej turze Pawła Kukiza. W drugiej turze wyborów młodzi wyborcy w większości zagłosowali na kandydata PiS-u Andrzeja Dudę. Szczególnie interesującym przypadkiem był wzrost poparcia dla byłego lidera zespołu „Piersi”. Jeszcze w lutym 2015 r. zastanawiano się, czy w ogóle zdobędzie on wymaganą ilość podpisów by móc kandydować, a w samych wyborach uzyskał on ponad $20 \%$ poparcie. P. Kukiz w trakcie kampanii określał siebie jako kandydata niezależnego, który idzie do wyborów tylko po to, aby wprowadzić w Polsce tzw. JOW-y, czyli jednomandatowe okręgi wyborcze. Większość jego wyborców to byli uczniowie szkół bądź studenci, którzy w ten sposób chcieli wykazać sprzeciw wobec obecnej klasy politycznej (Bańkowska, 2015).

\section{CZY JEST ALTERNATYWA DLA TZW. AMERYKANIZACJI KAMPANII WYBORCZYCH?}

KAŻDA INSTYTUCJA MUSI PODEJMOWAĆ DZIAEANIA, KTÓRE WZMOCNIĄ POZIOM zaufania do niej samej. Tak też się dzieje w przypadku partii politycznych. Te szczególnie muszą dbać o kreacje swojego pozytywnego wizerunku, szczególnie w okresie kampanijnym. Dzisiaj polityk (czy też dana partia) to produkt, który nabywa wyborca. Jest to marka, do której ludzie są przekonani bądź nie. Polskie kampanie wyborcze z lat 90-tych XX w. i z początku XXI w. determinowane były podziałem na obóz postkomunistyczny i postsolidarnościowy. Od $2005 \mathrm{r}$. mamy do czynienia z rywalizacją również dwóch obozów, ale o jednym już rodowodzie - dawnej opozycji antykomunistycznej. Od tego momentu sztaby wyborcze opracowując strategie dążą do jak największej personalizacji (kładą duży nacisk na cechy osobowościowe kandydata na urząd prezydenta, czy lidera danej partii) oraz profesjonalizacji (czyli wykorzystują na szeroką skalę ekspertów do spraw komunikacji). Starają się również narzucać pewne tematy w debacie publicznej, a także na dużą skalę wykorzystują reklamę negatywną wobec swoich oponentów. Wszystkie te elementy są coraz bardziej widoczne w kolejnych polskich kampaniach od 2005 r. Rozwój profesjonalizacji w polskich warunkach wpływa jednak na to, że wiele ugrupowań poli- 
tycznych tworząc strategie wyborcze coraz bardziej oddala się od bazowego elektoratu. Tworząc pewne hybrydowe koncepcje (które mają łączyć elementy programów partii socjaldemokratycznych, konserwatywnych oraz centrowych) trudno ugrupowaniom stworzyć profil stałego wyborcy. Podążając za radami ekspertów z dziedziny PR, partie i kandydaci odrzucają postulaty programowe, które w danej kampanii mogą być dla nich obciążeniem. Wydaje się, że tzw. amerykanizacja polskich kampanii dalej będzie postępować, a co za tym idzie w kolejnych latach będziemy na coraz większą skale obserwować zjawisko profesjonalizacji, ze wszystkimi negatywnymi tego konsekwencjami.

\section{Bibliografia:}

Alberski R. (2002), Wybory prezydenckie $w$ Polsce $w$ latach $1989-2000$ $i$ ich funkcje polityczne, [w]: Demokratyzacja $w$ III RP, red. A. Antoszewski, Wydawnictwo Uniwersytetu Wrocławskiego, Wrocław.

Bańkowska A., Wybory 2015. Skąd sukces Kukiza? Tu nie chodzi o JOW-y. „Gdyby spytać o nie jego wyborców...”, 11.05.2015, tokfm.pl, http://www. tokfm.pl/Tokfm/1,103087,178980o8,Wybory_2015_O_sukcesie_Kukiza_zadecydowaly_JOW_y_.html, 17.06.2015.

Błaszczak J., Kampanie sprzed lat: 1984, 08.09.2008, usa2008.blox.pl, http://usa2008.blox.pl/2008/o9/KAMPANIE-SPRZED-LAT-1984.html, 18.06.2015.

Czupryn A., Kilka dni z życia premiera, czyli tuskobusem $w$ Tusk de Pologne, 23.09.2011, polskatimes.pl, http://www.polskatimes.pl/artykul/453915,kilka-dni-z-zycia-premiera-czyli-tuskobusem-w-tusk-de,1,id,t,sa.html, 15.06.2015.

Dziedzic B., Miziołek M., Wojciechowska R., Spin doktorzy podkręcają polityke, 23.11.2013, polskatimes.pl, http://www.polskatimes.pl/artyku1/1049144,spin-doktorzy-podkrecaja-polityke,id,t.html, 16.06.2015.

Daniel K., Najstarszy polski spot negatywny (wybory prezydenckie 20oo), 09.04.2011, kampanianegatywna.pl, http://www.kampanianegatywna.pl/ filmy/26-najstarszy-polski-spot-negatywny-wybory-prezydenckie-20oo. html, 16.06.2015.

Grochal R. (2011), Czy Tusk poradzi sobie z pytaniem - Jak żyć ?, „Gazeta Wyborcza" z dnia 23.09.2011.

Jednaka W. (2002), Wybory parlamentarne w latach 1989 - 2001, [w]: Demokratyzacja $w$ III RP, red. A. Antoszewski, Wydawnictwo Uniwersytetu Wrocławskiego, Wrocław. 
Markowski R. (2007), System partyjny, [w]: Demokracja w Polsce 2005 2007, red. L. Kolarska - Bobińska, J. Kucharczyk, J. Zbieranek, Fundacja Instytut Spraw Publicznych, Warszawa.

Mazur M. (2010), Amerykanizacja polskich kampanii wyborczych?[w:] Profesjonalizacja i mediatyzacja kampanii wyborczych, red. K. Churska-Nowak, S. Drobczyński, Wydawnictwo WSNHiD, Poznań.

Mazur M. (2002), Marketing polityczny: studium porównawcze prezydenckich kampanii wyborczych $w$ USA i $w$ Polsce, Wydawnictwo Naukowe PWN, Warszawa.

Morozwski A., Szok wyborczy, 14.05.2007, historia.focus.pl, http://historia. focus.pl/swiat/szok-wyborczy-1022, 13.06.2015.

Pająk B., Patkowski K.(2007), Kampania negatywna w wyborach parlamentarnych i prezydenckich 2005, czyli paluszki i dziadek z Wermachtu atakują media, [w]: Media a polityka, red. A. M. Zarychta, Ł. Donaj, Wyższa Szkoła Studiów Międzynarodowych, Łódź.

Paradowska J., Tusk nie kandyduje na prezydenta. Między emocjami i realiami, 28.01.2010, polityka.pl, http://www.polityka.pl/tygodnikpolityka/ kraj/1502669,1,tusk-nie-kandyduje-na-prezydenta.read, 17.06.2015.

Peszyński W. (2008), Pozycjonowanie oferty politycznej LiD względem PiS w kampaniach 2006 i 2007 roku, [w]: Demokracja w Polsce po 2005 r., red. D. Karnowska, Wydawnictwo Adam Marszałek, Toruń.

Podobas I. (2012), Polityczny PR i rola „marki” $w$ kreowaniu wizerunku ugrupowań politycznych, [w:] Marketing polityczny. Doświadczenia polskie, red. R. Wiszniowski, A. Kasińska-Metryka, Wydawnictwo Adam Marszałek, Torun.

Raciborski J.(2003), Wybory i wyborcy, [w]: Demokracja polska 1989 2003, red. J. Wiatr, J. Raciborski, J. Bartkowski, B. Frątczak-Rudnicka, J. Kilias, Wydawnictwo Scholar, Warszawa.

Ratajczak M., Krótka historia marketingu politycznego w Polsce 1989 1995, 09.10.2009, epr.pl, http://www.epr.pl/krotka-historia-marketingupolitycznego-w-polsce-1989-1995,pr-w-polityce,1282,2.html, 14.06.2015.

Shultz W. (2006), Komunikacja polityczna. Koncepcje teoretyczne i wyniki badań empirycznych na temat mediów masowych $w$ polityce, Wydawnictwo Uniwersytetu Jagiellońskiego, Kraków.

Street J. (2006), Mass media, polityka, demokracja, Wydawnictwo Uniwersytetu Jagiellońskiego, Kraków.

Subotić M., Niewińska A. (2011), Kampania na wysokich obcasach, „Rzeczpospolita" z dnia 24-25.09.2011. 
Szacki W., Jarosław Kaczyński do przyjaciół Moskali, 10.05.2010, wyborcza. pl, http://wyborcza.pl/1,76842,7861316,Jaroslaw_Kaczynski_do_przyjaciol_Moskali.html, 16.06.2015.

Sztumski J. (1990), Propaganda - jej problemy i metody, Wydawnictwo Uniwersytetu Śląskiego, Katowice.

Święćkowska T. (2008), Public relations a demokracja, Wydawnictwa Uniwersytetu Warszawskiego, Warszawa.

Węgorzecki J. (2008), Demokracja w Polsce 2005 - 2007: fakty i opinie, [w]: Demokracja $w$ Polsce po 2005 roku, red. D. Karnowska, Wydawnictwo Adam Marszałek, Torun.

Wiatr J.(2003), Pięć parlamentów III Rzeczypospolitej, [w]: Demokracja polska 1989 - 2003, red. J. Wiatr, J. Raciborski, J. Bartkowski, B. Frątczak-Rudnicka, J. Kilias, Wydawnictwo Scholar, Warszawa.

Wiszniowski R.(2000), Marketing wyborczy. Studium kampanii wyborczych $w$ systemach prezydenckich $i$ semiprezydenckich (Finlandia, Francja, Polska, Stany Zjednoczone), Wydawnictwo Naukowe PWN, Warszawa - Wrocław.

Wójcik K. (2009), Public relations. Wiarygodny dialog z otoczeniem. Podręcznik dla teoretyków. Poradnik dla praktyków, Wydawnictwo Placet, Warszawa.

Wróblewski R. (2007), Wyrażanie uczuć w telewizyjnej kampanii wyborczej L. Watęsy i A. Kwaśniewskiego podczas wyborów prezydenckich $w 1995$ r., [w]: Media a polityka, red. A. M. Zarychta, Ł. Donaj, Wyższa Szkoła Studiów Międzynarodowych, Łódź.

Wybory 2010. Prawybory $w$ PO przyćmity innych kandydatów, 23.03.2010, gazeta.pl, http://wiadomosci.gazeta.pl/wiadomosci /1,114873,7686877,Wybory_2010__Prawybory_w_PO_przycmily_innych_kandydatow.html, 17.06.2015 r.

\section{SUMMARY}

Creating the image of politicians is always a deliberate act. PR should be a reliable source of information about politicians or party. Very often the image of a political party or a politician is being built exclusively on the basis of media coverage. It seems that success in politics inevitably connects with a good presentation in the media. The experience of Polish political PR is only 25 years old. This can not be compared with the experiences of western countries, especially the United 
States. However, even in this period, we have seen a very well-run election campaigns, but also those which were conducted incompetently.

\section{NotA O AUTORZE}

Jarosław Kardaś [jaroslaw.kardas@amu.edu.pl] - absolwent dwóch kierunków - Politologii (specjalność: Marketing polityczny) oraz Dziennikarstwa i komunikacji społecznej (specjalność: Dziennikarstwo oraz Reklama i promocja) na Wydziale Nauk Politycznych i Dziennikarstwa Uniwersytetu im. Adama Mickiewicza w Poznaniu. Obecnie doktorant na tym samym Wydziale. Jego głównymi zainteresowaniami badawczymi są stosunki międzynarodowe na obszarze Kaukazu Południowego oraz kształtowanie wizerunku polityków w mediach. 